\title{
Antiprogestins RU486 and ZK299 suppress basal and LHRH-stimulated FSH and LH secretion at pituitary level in the rat in an oestrous cycle stage-dependent manner
}

\author{
C Bellido, D Gonzalez, R Aguilar and J E Sánchez-Criado \\ Department of Physiology, Faculty of Medicine, University of Córdoba, Córdoba, Spain \\ (Requests for offprints should be addressed to J E Sánchez-Criado, Department of Physiology, Faculty of Medicine, Avda. Menendez Pidal s/n, \\ 14004 Córdoba, Spain)
}

\begin{abstract}
We have previously shown that administration of antiprogestin (AP) type II RU486 to ovariectomized (OVX) rats on the morning of pro-oestrus decreases the magnitude of the preovulatory gonadotrophin surge. This suggests that the effect of RU486 on LHRH-dependent gonadotrophin release may be independent of its ability to block progesterone actions. The aim of the present research was to study the possible site of RU486 action and to determine whether the gonadotrophin-suppressive effect of APs RU486 and ZK299 is dependent on the oestrogen background.

Intact or OVX rats in the morning of pro-oestrus were injected s.c. with $4 \mathrm{mg}$ RU486 or ZK299 (AP type I) at $0900 \mathrm{~h}$ on pro-oestrus. At $1830 \mathrm{~h}$, serum concentrations of FSH and LH and median eminence (ME) content of LHRH were determined. In the second experiment, the effect of RU486 and ZK299 on pituitary responsiveness to LHRH (100 ng, i.p.) and ME content of LHRH at $1830 \mathrm{~h}$ in pentobarbital (PB)-blocked intact or OVX rats was evaluated. In the last study, the anterior pituitary release of
\end{abstract}

FSH and $\mathrm{LH}$ from pro-oestrous or metoestrous donors incubated with or without LHRH $(1,10$ or $100 \mathrm{nM})$ in the presence or absence of APs $(20 \mathrm{nM})$ was evaluated.

Both APs reduced serum FSH and LH levels at $1830 \mathrm{~h}$ on pro-oestrus in intact and OVX rats. The suppressive effect on gonadotrophin release brought about by AP treatment was also evidenced in PB-blocked intact and OVX rats. This suggested that the inhibitory effect of APs occurred, at least in part, at the pituitary level. Furthermore, in the absence of the natural ligand, APs significantly reduced basal and LHRH-stimulated FSH and LH release from pro-oestrous but not metoestrous pituitaries.

In conclusion, these experiments have shown, both in vivo and in vitro, that APs RU486 and ZK299 have suppressive effects at the pituitary level on basal and LHRH-stimulated FSH and LH secretion, regardless of their antiprogestagenic activity, in pro-oestrus but not in metoestrus.

Journal of Endocrinology (1999) 163, 79-85

\section{Introduction}

In the cyclic rat, progesterone inhibits or stimulates gonadotrophin secretion depending on the time of the oestrous cycle. From oestrus throughout dioestrus, progesterone potentiates the negative feedback effects of oestradiol; during pro-oestrus, progesterone facilitates the preovulatory release of gonadotrophins (Rao \& Mahesh 1986, Mahesh \& Muldoon 1987, Brann \& Mahesh 1991, Brann et al. 1991), allows the expression of the folliclestimulating hormone (FSH) secondary surge during early oestrus (Knox et al. 1993, Tébar et al. 1995a,b), and extinguishes, $24 \mathrm{~h}$ later, the neural signal controlling gonadotrophin surge (Freeman et al. 1976, Lustig et al. 1988).

In 1989, Ortmann et al., using primary cultures of pituitary cells from female rats, reported that the anti- progestin (AP), RU486, an antiprogestagen at the receptor with antiglucocorticoid activity (Baulieu 1989), abolished the facilitatory and inhibitory actions of progesterone on luteinizing hormone-releasing hormone (LHRH)induced luteinizing hormone (LH) secretion. They also reported that RU486 itself reduced the $\mathrm{LH}$ response to LHRH and that this inhibitory effect is enhanced in the presence of oestrogen, attributing such direct inhibitory action of RU486 to a non-specific toxic or pharmacological effect of the compound (Ortmann et al. 1989).

Pro-oestrous administration of RU486 to cyclic rats reduces serum concentrations of FSH and $\mathrm{LH}$ on the pro-oestrous afternoon in both intact (Rao \& Mahesh 1986) and ovariectomized (OVX) rats (Tébar et al. 1996), whereas OVX itself on the morning of pro-oestrus has no effect (Tébar et al. 1996). These and other findings 
have given rise to the hypothesis that activation of oestrogen-dependent progesterone receptor (PR) through a ligand-independent mechanism may be involved in the regulation of reproductive processes (Waring \& Turgeon 1992, Turgeon \& Waring 1994, Szabo et al. 1996, Levine 1997, Cenni \& Picard 1999, Sánchez-Criado et al. 1999). The physiological relevance of these findings is not yet known.

The aim of the present study was to determine, in vivo and in vitro, whether APs RU486 (type II) and ZK299 (type I), which differ in the mechanism of action (KleinHitpass et al. 1991, Beck et al. 1996), affect, directly at the pituitary, LHRH-dependent LH and FSH secretion in female rats. Results showed that in pro-oestrus, but not in metoestrus, APs reduced basal and LHRH-stimulated LH and FSH secretion at the pituitary level regardless of the natural ligand.

\section{Materials and Methods}

\section{Animals}

Adult cyclic female Wistar rats weighing 185-210 g were used. The rats were housed under a $14 \mathrm{~h}$ light: $10 \mathrm{~h}$ darkness schedule, with lights on at $0500 \mathrm{~h}$ and at $21-23{ }^{\circ} \mathrm{C}$ room temperature. Vaginal smears were taken daily and only rats showing consistent 4 -day cycles were used in these experiments.

\section{Drug treatments and surgery}

APs RU486 (11 $\beta$-[4-dimethyl-aminophenyl]-17 $\beta$-hydroxy17 $\alpha$-[prop-1-inyl]-estra-4,9-diene-3-one) (Exelgyn, Paris, France) (Philibert et al. 1985) and ZK299 (11ß[4-dimethyl-aminopropyl]-17 $\alpha$-hydroxy-17 $\beta$-[3-hydroxy propyl]-13a-methyl-4,9 gonadien-3-one) (Schering, Berlin, Germany) (Neef et al. 1984) were suspended in olive oil at a concentration of $20 \mathrm{mg} / \mathrm{ml}$. Rats were injected s.c. at $0900 \mathrm{~h}$ on pro-oestrus with $0 \cdot 2 \mathrm{ml}$ of these suspensions. Controls were given $0 \cdot 2 \mathrm{ml}$ oil.

OVX or control sham-OVX was performed under light ether anaesthesia at $0900 \mathrm{~h}$ on pro-oestrus.

In order to block endogenous LHRH release, rats were given an i.p. injection of $60 \mathrm{mg} / \mathrm{kg}$ sodium pentobarbitone (PB) (Sanofi Sante, Libourne Cedex, France) at $1300 \mathrm{~h}$ on pro-oestrus.

Synthetic LHRH (Peninsula 7201; Peninsula Laboratory, Inc., Merseyside, UK) was dissolved in saline at a concentration of $200 \mathrm{ng} / \mathrm{ml}$, and $0.5 \mathrm{ml}$ of this solution was injected i.p. at $1600 \mathrm{~h}$ on pro-oestrus. Control injections consisted of $0.5 \mathrm{ml}$ saline.

\section{Collection of serum and tissues}

Rats were killed by decapitation at $1830 \mathrm{~h}$ on pro-oestrus. Trunk blood was collected, allowed to clot, and centri- fuged at $24{ }^{\circ} \mathrm{C}$ for $10 \mathrm{~min}$. Serum was stored frozen at $-20{ }^{\circ} \mathrm{C}$ until assayed for $\mathrm{LH}$ and $\mathrm{FSH}$. The median eminence (ME) was dissected under a stereomicroscope using fine iris scissors and homogenized (ultrasound) in $100 \mu \mathrm{l} 0 \cdot 1 \mathrm{M}$ acetic acid. After centrifugation, supernatants were stored frozen at $-20{ }^{\circ} \mathrm{C}$ until assayed for LHRH.

\section{Experiments}

The first experiment studied the effects of RU486 and ZK299 on serum LH and FSH concentrations and on ME LHRH content at $1830 \mathrm{~h}$ on pro-oestrus in OVX or sham-OVX rats. In the second experiment we evaluated the pituitary responsiveness in vivo to $L H R H$ in rats injected with APs. For this purpose, OVX and shamOVX rats were injected with $\mathrm{PB}$ on pro-oestrus to prevent endogenous release of LHRH and administered with LHRH. Finally, in the third experiment, pituitaries from pro-oestrous or metoestrous rats were rapidly removed at $1000 \mathrm{~h}$. The posterior lobe was dissected and discarded. The anterior pituitaries were cut in half and the halves divided into four parts. Fragments from each hemipituitary were incubated in medium only or in medium containing 1,10 or $100 \mathrm{nM} \mathrm{LHRH}$ in the presence or absence of $20 \mathrm{nM} \mathrm{RU486}$ or ZK299.

\section{Incubation of pituitaries}

Pituitaries were incubated in glass scintillation vials in a Dubnoff shaker at $37^{\circ} \mathrm{C}$ with constant shaking (60 cycles/ $\mathrm{min})$ in an atmosphere of $95 \% \mathrm{CO}_{2}-5 \% \mathrm{O}_{2}$. Each vial contained $1 \mathrm{ml}$ Dulbecco's modified Eagle's medium with $4.5 \mathrm{~g} / 1$ glucose without L-glutamine or phenol red containing BSA $(0 \cdot 1 \%, \mathrm{w} / \mathrm{v})$. The $\mathrm{pH}$ was $7 \cdot 4$. At the end of preincubation $(60 \mathrm{~min})$, pituitaries were incubated for 120 min with medium only, or with medium containing $20 \mathrm{nM}$ RU486 or ZK299; thereafter, the incubation medium was removed, immediately frozen until assayed for FSH and LH and replaced by fresh medium containing, in addition to RU486 or ZK299, 1, 10 or $100 \mathrm{nM}$ LHRH. At the end of the second incubation period (120 min), the medium was immediately frozen until assayed for $\mathrm{LH}$ and FSH.

\section{RIAs}

Serum LH and FSH concentrations were measured in duplicate $25 \mu \mathrm{l}$ aliquots using double-antibody RIA methods with RIA kits supplied by NIH (Bethesda, MD, USA) and a previously described microassay method (Sáchez-Criado et al. 1990). Rat LH-I-9 and FSH-I-8 were labelled with ${ }^{125} \mathrm{I}$ by the chloramine $\mathrm{T}$ method (Greenwood et al. 1963). In order to obviate interassay variability, all samples were analysed in the same assay. Intra-assay coefficients of variation were 7 and $8 \%$ for $\mathrm{LH}$ 
and FSH respectively. Assay sensitivities were 7.5 and $50 \mathrm{pg} /$ tube for LH and FSH respectively. Serum LH and FSH concentrations were expressed as $\mathrm{ng} / \mathrm{ml}$ of serum of the reference preparation LH-rat-RP-3 and FSH-rat$\mathrm{RP}-2$ respectively.

LHRH content from ME was measured in duplicate using previously characterized LHRH antibody HU-60 provided by Dr H F Urbanski (Neuroscience Division, Oregon Regional Primate Research Center, Beaverton, OR, USA), and synthetic LHRH (Peninsula 7201) as the reference standard and for labelling with ${ }^{125} \mathrm{I}$. Details of this assay have previously been published (Sánchez-Criado et al. 1993, 1994). In order to avoid any interassay variability, all samples were run in the same assay. Intraassay variability was $9 \%$, and the assay sensitivity was $0 \cdot 25 \mathrm{pg} /$ tube. LHRH content was expressed as ng/ME.

\section{Statistical analysis}

Results are expressed as means \pm s.E.M. Data were analysed by two-way ANOVA using the Newman-Keuls multiple range test when two means had to be compared. Results were considered significant at $P<0 \cdot 05$.

\section{Results}

Effect of AP treatment on ME LHRH content, serum FSH and $L H$ concentration on the pro-oestrous afternoon in intact and OVX rats

OVX had no significant effect on either ME LHRH content or serum LH concentrations on the pro-oestrous afternoon but doubled FSH levels as expected (Fig. 1). Administration of RU486 or ZK299 significantly reduced serum LH and FSH concentrations in both intact and OVX rats without affecting ME LHRH content (Fig. 1).

\section{Effectiveness of $P B$ and $L H R H$ in blocking and stimulating} FSH and $\mathrm{LH}$ release respectively

Administration of $\mathrm{PB}$ increased significantly $(P<0 \cdot 05)$ ME LHRH content (Figs 1 and 2) and suppressed serum FSH $(2 \cdot 9 \pm 2 \cdot 0 \mathrm{ng} / \mathrm{ml})$ and $\mathrm{LH}(1.9 \pm 0.8 \mathrm{ng} / \mathrm{ml})$ concentrations with respect to the control values $(10 \cdot 9 \pm 1 \cdot 6$ and $11 \cdot 1 \pm 2 \cdot 6 \mathrm{ng} / \mathrm{ml}$ respectively) on the pro-oestrous afternoon. LHRH injection to PB-blocked rats restored normal serum FSH $(11.1 \pm 2.5 \mathrm{ng} / \mathrm{ml})$ and LH $(12.7 \pm$ $2 \cdot 9 \mathrm{ng} / \mathrm{ml})$ levels.

\section{Effect of AP treatment on pituitary responsiveness to LHRH} on the pro-oestrous afternoon in intact and OVX rats

LHRH injection restored normal FSH and LH serum levels on the pro-oestrous afternoon in PB-blocked intact or OVX rats. The stimulating effect of LHRH on FSH

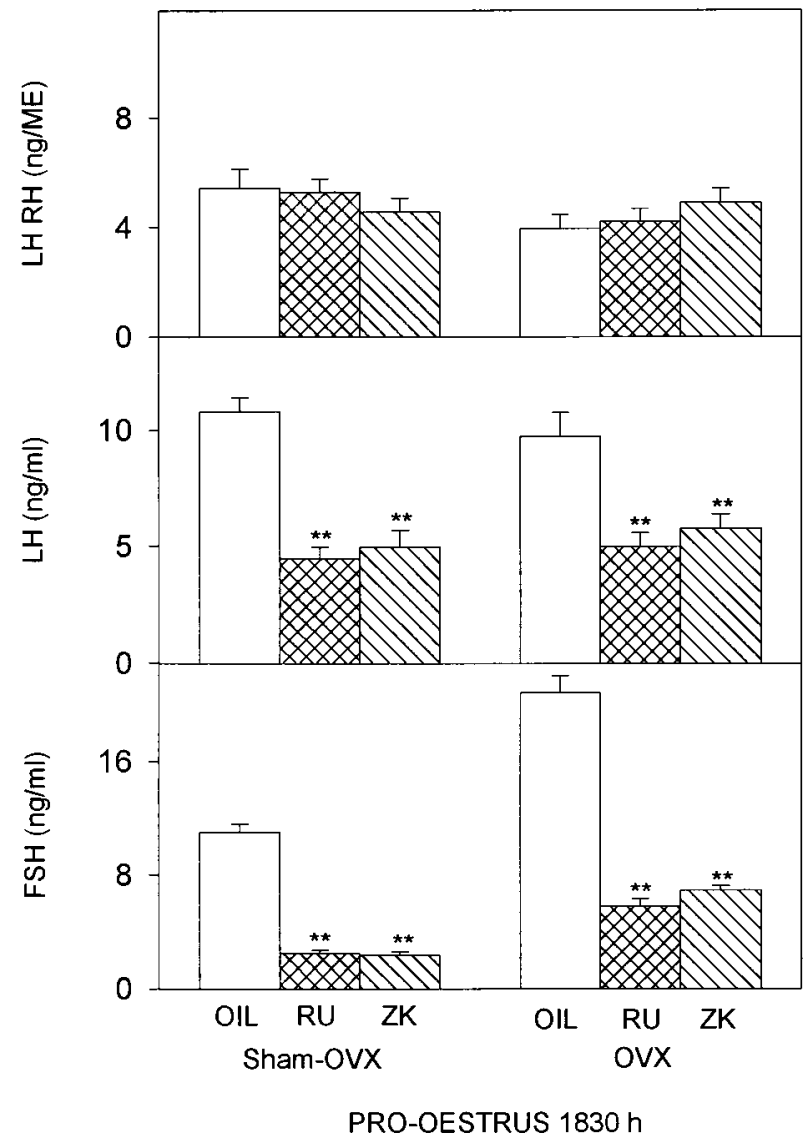

Figure 1 LHRH ME content and serum LH and FSH concentration at $1830 \mathrm{~h}$ on pro-oestrus in intact and OVX rats injected (s.c.) with $4 \mathrm{mg}$ RU486 (RU) or ZK299 (ZK) at $0900 \mathrm{~h}$ on pro-oestrus. Control injections were $0 \cdot 2 \mathrm{ml}$ oil. Values are means \pm S.E.M. of $10-15$ rats. ${ }^{*} P<0 \cdot 01$ vs oil-injected rats; ANOVA and Newman-Keuls multiple range test.

and LH secretion was significantly blunted in both intact and OVX rats treated with RU486 or ZK299 (Fig. 2).

Effect of APs on basal and LHRH-stimulated LH and FSH release in incubated pituitaries from rats in the pro-oestrous or metoestrous morning

The release of LH and FSH in the absence of LHRH did not differ significantly after the first or the second incubation period. Exposure of pituitaries to LHRH during the last $120 \mathrm{~min}$ increased $\mathrm{LH}$ and FSH release in a dose-dependent manner. The maximum LHRHstimulated LH release was about 10 -fold for prooestrous ( $58 \pm 21$ vs $565 \pm 104 \mathrm{ng} /$ hemihypophysis) or metoestrous pituitaries ( $29 \pm 5$ vs $272 \pm 38 \mathrm{ng}$ / hemihypophysis). LHRH-induced FSH secretion was only $3 \cdot 5$-fold, and no differences were observed between basal or LHRH-stimulated FSH from pro-oestrous 


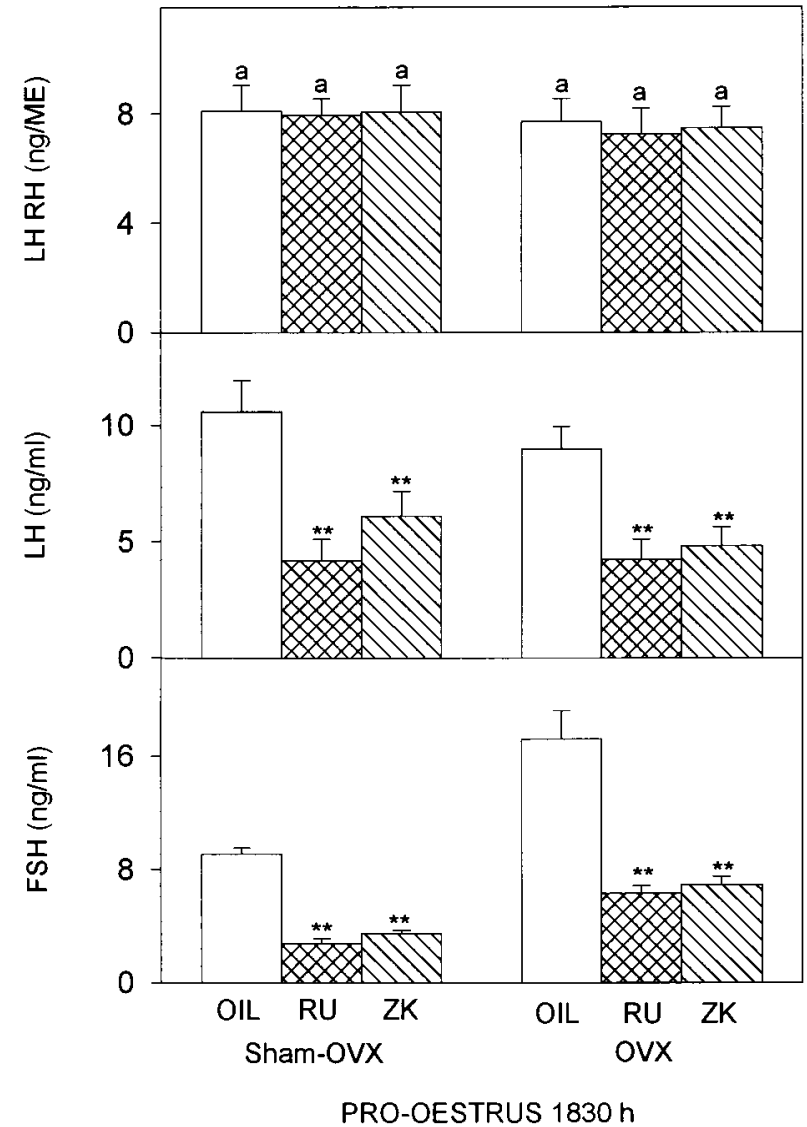

Figure 2 LHRH ME content and pituitary responsiveness (serum $\mathrm{LH}$ and FSH concentrations) to LHRH (100 ng/0.5 ml saline, i.p.) at $1600 \mathrm{~h}$ on pro-oestrus in PB-blocked OVX or sham-OVX rats at $0900 \mathrm{~h}$ on pro-oestrus and injected (s.c.) with $4 \mathrm{mg}$ RU486 (RU) or ZK299 (ZK) at the same time. Control injections were $0 \cdot 2 \mathrm{ml}$ oil. Values are means \pm S.E.M. of $10-15$ rats. ${ }^{* *} P<0 \cdot 01$ vs oil-injected rats; $a=P<0.05$ vs the corresponding value in non-PB-blocked rats (Fig. 1); ANOVA and Newman-Keuls multiple range test.

(15 \pm 2 vs $45 \pm 4 \mathrm{ng} /$ hemihypophysis) or metoestrous (14 \pm 1 vs $48 \pm 4$ ng/hemihypophysis) pituitaries (Fig. 3).

Both RU486 and ZK299 reduced basal and LHRHstimulated LH and FSH release from pro-oestrous pituitaries. Although differences were not statistically significant, RU486 appeared to be more efficient in terms of its suppressive effect than ZK299 (Fig. 3). However, no effects were observed on basal and stimulated LH or FSH release in metoestrus pituitaries.

\section{Discussion}

The main findings of the present in vivo study were that the blockade of activation of PR with the APs RU486 and ZK299 reduced, at the time of spontaneous gonadotrophin

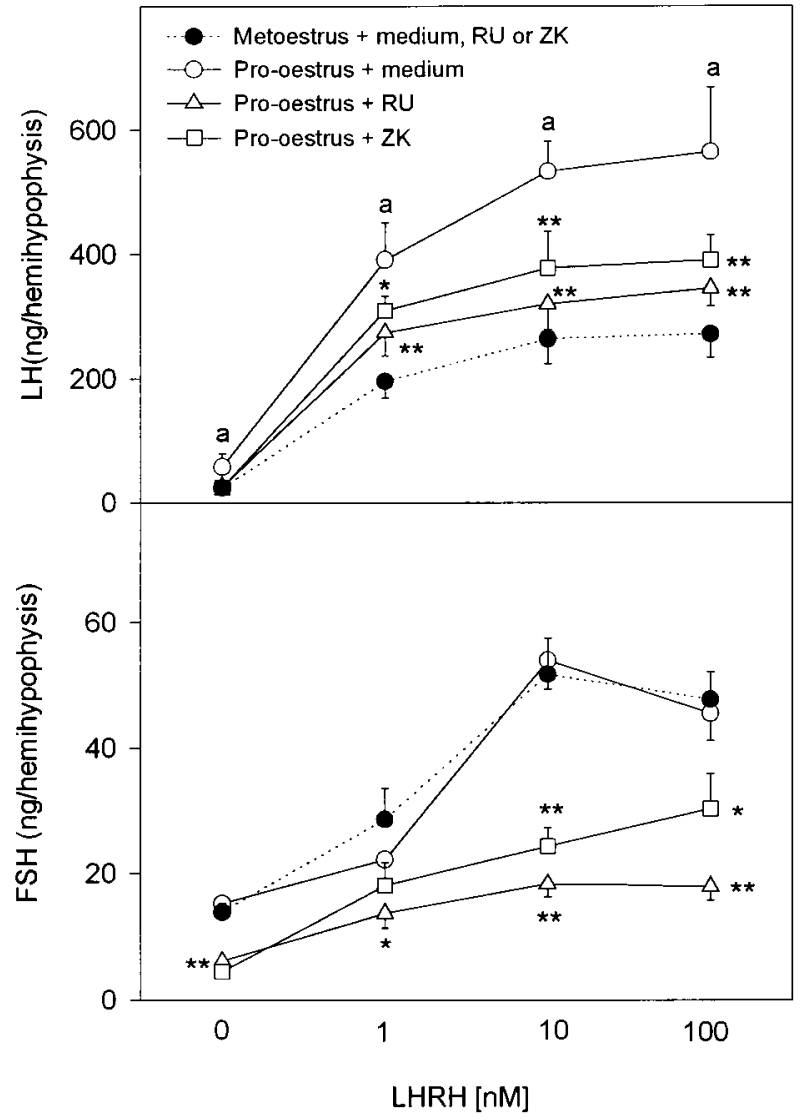

Figure 3 Effect of $20 \mathrm{nM}$ RU486 (RU) and ZK299 (ZK) on LH and FSH release by pro-oestrous or metoestrous morning pituitaries incubated for $4 \mathrm{~h}$ in medium only or in medium with LHRH $(1,10$ or $100 \mathrm{nM}$ ). Means \pm S.E.M. of eight observations. Since no differences were found in $\mathrm{LH}$ or FSH release from metoestrous morning pituitaries incubated with medium alone, RU or ZK, they are shown together. $\mathrm{a}=P<0.01 \mathrm{vs}$ metoestrous pituitaries; ${ }^{*} P<0.05$ and ${ }^{* *} P<0 \cdot 01$ vs pro-oestrous pituitaries incubated with medium only; ANOVA and Newman-Keuls multiple range test.

surge, $\mathrm{LH}$ and FSH secretion in intact and OVX rats, and that RU486 and ZK299 reduced the ability of exogenous $\mathrm{LHRH}$ to restore FSH and $\mathrm{LH}$ surges in PB-blocked intact and OVX rats. These results suggest that: (i) the effects of the steroid antagonists on FSH and LH secretion were not due to antagonizing the action of pro-oestrous progesterone from ovarian origin; and (ii) both RU486 and ZK299 interfered with LHRH action at the pituitary level. Although adrenal hormones may be involved in gonadotrophin secretion in the pro-oestrous afternoon (Brann et al. 1991, Putnam et al. 1991) and RU486 also blocks glucocorticoid actions (Moguilewsky \& Philibert 1984, Beck et al. 1993), the findings of these experiments that ZK299, which has about 20-fold lower binding affinity to glucocorticoid receptor than does RU486 (Neef et al. 1984), suppressed LH and FSH secretion 
similarly (Figs 1 and 2), suggest that, under the present experimental conditions, adrenal hormones are not involved. This interpretation was supported by the findings of the third experiment, in which, in the absence of cognate ligands (progesterone and glucocorticoids), APs significantly reduced basal and LHRH-stimulated secretion of FSH and LH by incubated pituitaries from pro-oestrous donors. However, APs had no effect on either basal or LHRH-stimulated FSH and LH release in incubated pituitaries from metoestrous donors or when injected on metoestrus in OVX rats (Sánchez-Criado et al. 1993). These observations indicated that the suppressive effect of APs on FSH and LH secretion, in vivo and in vitro, is dependent on the stage of the oestrous cycle.

The preovulatory increase of serum oestradiol concentration from metoestrus to pro-oestrus (Smith et al. 1975) is the primary stimulus for the increase in pituitary responsiveness to LHRH (Aiyer et al. 1976). This oestrogen dependency, together with the expression of a neural signal for LH release in the form of a surge of LHRH (Everett \& Sawyer 1950), brings about the preovulatory surge of LH (reviewed by Fink 1988). The in vitro results of the present study coincide fully with this concept; at pro-oestrus, the pituitary released more LH than at metoestrus. However, no differences in FSH release were observed between pro-oestrus and metoestrus. This finding suggested that a high oestrogen background on prooestrus is essential for the release of LH but not of FSH, reflecting the strong inhibitory ovarian influences on the secretory character of FSH (Muyan et al. 1994, Farnworth 1995) throughout the oestrous cycle (Arai et al. 1996). This contrasts with the negative (dioestrous phase) and positive (pro-oestrus) feedback effect of oestrogen (Arai et al. 1996) on LHRH-dependent LH secretion. Nevertheless, the importance of oestrogen-inducible PR in the pituitary (MacLusky \& McEwen 1978) for determining the inhibitory action of RU486 and ZK299, is similar for both gonadotrophins. This is because APs reduced basal and LHRH-stimulated secretion of both FSH and $\mathrm{LH}$ in pro-oestrus but not in metoestrus.

These results, as well as those obtained previously (Ortmann et al. 1989, Waring \& Turgeon 1992, Turgeon \& Waring 1994), suggest that when there is a high rate of LHRH-dependent gonadotrophin secretion, ligand-dependent and ligand-independent activation of oestrogen-inducible PR converge and facilitate FSH and LH secretion. Since activation of PR enhances the sensitivity of the pituitary to LHRH (McPherson \& Mahesh 1979, Sarkar \& Fink 1979) and enhances the action of several pituitary responsiveness factors (Bauer-Dantoin et al. 1993, Sahu et al. 1997, Szabo et al. 1998), the intrinsic mechanism of the inhibitory effects of APs on LHRH-dependent gonadotrophin secretion has yet to be determined.

With the exception of gonadotrophin secretion in pro-oestrus, which is strictly dependent on LHRH (Sarkar et al. 1976, Blake \& Kelch 1981, present results), the control of FSH and LH secretion diverges under a variety of physiological and experimental conditions. Transient LHRH-independent FSH release (Hasegawa et al. 1981) during the oestrous cycle of the rat occurs after unilateral OVX on metoestrus and during the early hours of oestrus (secondary surge of FSH), due to the release of stimulatory actions of activin-B within the anterior pituitary (DePaolo et al. 1992) brought about by the surgical or physiological decrease in ovarian inhibin secretion (Hasegawa et al. 1989). Administration of APs blocks the LHRHindependent transient FSH surges after unilateral OVX on metoestrus (Sánchez-Criado et al. 1992a) and at early oestrus (Knox \& Schwartz 1992, Sánchez-Criado et al. 1992b). Recent experiments have shown that this action of RU486 is the consequence of the blockade of ligandindependent activation of oestrogen-inducible PR (Knox et al. 1996, Szabo et al. 1996), probably interfering with activin-mediated signal transduction to stimulate FSH secretion in the absence of circulating inhibin (Szabo et al. 1998).

Blockade of PR activation by administration of RU486 on metoestrus has no effect on either FSH or LH serum concentrations in OVX rats (Sánchez-Criado et al. 1993). Furthermore, the results obtained here show that, in the absence of the natural ligand, APs did not interfere with basal and LHRH-stimulated FSH or LH secretion in incubated pituitaries from metoestrous donors. These findings show that during the low secretion rate of gonadotrophin (dioestrous phase), APs block only the ovarian progesterone inhibitory effect of activation of oestrogen-inducible PR during metoestrus (Ortmann et al. 1989).

Bearing in mind results obtained previously, the present data support the hypothesis that stimulation of $\mathrm{LH}$ and/or FSH release (LHRH-dependent preovulatory surge of LH and FSH on the pro-oestrous afternoon and activinstimulated secondary surge of FSH during early oestrus), which account for ovulation and follicular recruitment respectively, is ensured by synergistic ligand-independent and ligand-dependent activation of $\mathrm{PR}$ at hypothalamic (Lee et al. 1990, Sánchez-Criado et al. 1994, Levine 1997) and/or pituitary levels (present results). In contrast, during the period of low secretion rate of gonadotrophins, inhibition of FSH (from late oestrus and throughout the dioestrous phase) and LH (from early oestrus up to dioestrous phase) secretion due to $\mathrm{PR}$ activation is associated with ovarian progesterone action.

\section{Acknowledgements}

We wish to thank Dr R Sitruk-Ware and W Elger for generously providing RU486 and ZK299 respectively, and we are also grateful to the National Hormone and Pituitary Program (Baltimore, MD, USA) for the LH and 
FSH RIA kits. This study was subsidized by grants (APC98-0148 and PM98-0167) from DGESEIC, Spain.

\section{References}

Aiyer MS, Sood MD \& Brown-Grant K 1976 The pituitary response to exogenous luteinizing hormone releasing factor in steroid treated gonadectomized rats. Journal of Endocrinology 69 255-262.

Arai K, Watanabe G, Taya K \& Sasamoto S 1996 Roles of inhibin and estradiol in the regulation of follicle-stimulating hormone and luteinizing hormone secretion during the estrous cycle of the rat. Biology of Reproduction 55 127-133.

Bauer-Dantoin AC, Tabesh B, Norgle JR \& Levine JE 1993 RU486 administration blocks neuropeptide Y potentiation of luteinizing hormone (LH)-releasing hormone-induced $\mathrm{LH}$ surges in proestrous rats. Endocrinology 133 2418-2423.

Baulieu EE 1989 Contragestion and other clinical applications of RU486, an antiprogestagen at the receptor. Science 245 1315-1357.

Beck CA, Estes PA, Bona BJ, Muro-Cacho CA, Nordeen SK \& Edwards DP 1993 The steroid antagonist RU486 exerts different effects on the glucocorticoid and progesterone receptors. Endocrinology 133 728-740.

Beck CA, Zhang Y, Weigel NL \& Edwards DP 1996 Two types of antiprogestins have distinct effects on site-specific phosphorylation of human progesterone receptors. Journal of Biological Chemistry 271 1209-1217.

Blake ChA \& Kelch RP 1981 Administration of antiluteinizing hormone-releasing hormone serum to rats: effects on periovulatory secretion of luteinizing hormone and follicle-stimulating hormone. Endocrinology 109 2175-2179.

Brann DW \& Mahesh VB 1991 Regulation of gonadotropin secretion by steroid hormones. Frontiers in Neuroendocrinology 12 165-207.

Brann DW, Putnam CD \& Mahesh VB 1991 Validation of the mechanism proposed for the stimulatory and inhibitory effects of progesterone on gonadotropin secretion in the estrogen-primed rat: a possible role for adrenal steroids. Steroids 56 103-111.

Cenni B \& Picard D 1999 Ligand-independent activation of steroid receptors: new roles for old players. Trends in Endocrinology and Metabolism 10 41-46.

DePaolo LV, Bald LN \& Fendly BM 1992 Passive immunoneutralization with a monoclonal antibody reveals a role for endogenous activin-B in mediating FSH hypersecretion during estrus and following ovariectomy of hypophysectomized, pituitary-grafted rats. Endocrinology 130 1741-1743.

Everett JW \& Sawyer CH 1950 A 24-h periodicity in the LH-release apparatus' of female rats, disclosed by barbiturate sedation. Endocrinology 47 198-218.

Farnworth PG 1995 Gonadotrophin secretion revisited. How many ways can FSH leave a gonadotroph? Journal of Endocrinology 145 387-395.

Fink G 1988 Gonadotropin secretion and its control. In The Physiology of Reproduction, pp 1346-1377. Eds E Knobil \& J Neill. New York: Raven Press.

Freeman ME, Dupke KC \& Croteau CM 1976 Extinction of the estrogen-induced daily signal for LH release in the rat: a role for proestrous surge of progesterone. Endocrinology 99 223-229.

Greenwood FC, Hunter WM \& Glover JS 1963 The preparation of 131-I-labeled human growth hormone of high specific radioactivity. Biochemical Journal 89 114-123.

Hasegawa Y, Miyamoto K, Yazaki C \& Igarashi M 1981 Regulation of the second surge of follicle-stimulating hormone; effects of antiluteinizing hormone-releasing hormone serum and pentobarbital. Endocrinology 109 130-135.

Hasegawa Y, Miyamoto K \& Igarashi M 1989 Changes in serum concentrations of immunoreactive inhibin during the oestrous cycle of the rat. Journal of Endocrinology 121 91-100.
Klein-Hitpass L, Cato ACB, Henderson D \& Ryffel GU 1991 Two types of antiprogestins identified by their differential action in transcriptionally active extracts from T47D cells. Nucleic Acid Research 19 47-52.

Knox KL \& Schwartz NB 1992 RU486 blocks the secondary surge of follicle-stimulating hormone in the rat without blocking the drop in serum inhibin. Biology of Reproduction 46 220-225.

Knox KL, Ringstrom SJ \& Schwartz NB 1993 RU486 blocks the effects of inhibin or luteinizing hormone on the secondary follicle-stimulating hormone surge. Endocrinology 133 277-283.

Knox KL, Ringstrom SJ, Szabo M, Perlyn CA, Sutandi S \& Schwartz NB 1996 RU486 on an estrogen background blocks the rise in serum follicle-stimulating hormone induced by antiserum to inhibin or ovariectomy. Endocrinology 137 1226-1232.

Lee WS, Smith S \& Hoffman GE 1990 Progesterone enhances the surge of luteinizing hormone by increasing the activation of luteinizing hormone-releasing hormone neurons. Endocrinology 127 2604-2606.

Levine JE 1997 New concepts of the neuroendocrine regulation of gonadotropin surges in rats. Biology of Reproduction 56 293-302.

Lustig RH, Pfaff DW \& Fishman J 1988 Induction of LH hypersecretion in cyclic rats during the afternoon of oestrus by oestrogen in conjunction with progesterone antagonism or opioidergic blockade. Journal of Endocrinology 117 229-235.

MacLusky NJ \& McEwen BS 1978 Oestrogen modulates progestin receptor concentrations in some brain regions but not in others. Nature 274 276-278.

Mahesh VB \& Muldoon ThG 1987 Integration of the effects of estradiol and progesterone in the modulation of gonadotropin secretion. Journal of Steroid Biochemistry 27 665-675.

McPherson JC \& Mahesh VB 1979 Dose related effects of a single injection of progesterone on gonadotropin secretion and pituitary sensitivity to LHRH in estrogen-primed castrate female rats. Biology of Reproduction 20 763-772.

Moguilewsky M \& Philibert D 1984 RU38486: potent antiglucocorticoid activity correlated with strong binding to the cytosolic glucocorticoid receptor followed by an impaired activation. Journal of Steroid Biochemistry 20 271-276.

Muyan M, Ryzmkiewicz DM \& Boime I 1994 Secretion of lutropin and follitropin from transfected $\mathrm{GH}_{3}$ cells: evidence for separate secretory pathways. Molecular Endocrinology 8 1789-1797.

Neef G, Beier S, Elger W, Henderson D \& Wiechert R 1984 New steroid with antiprogestational and antiglucocorticoid activities. Steroids 44 349-372.

Ortmann O, Emons G, Knuppen R \& Catt KJ 1989 Inhibitory effects of the antiprogestin, RU486, on progesterone actions and luteinizing hormone secretion in pituitary gonadotrophs. Journal of Steroid Biochemistry 32 291-297.

Philibert D, Moguilewsky M, Mary I, Lecaque D, Tournemine C, Secchi J \& Deraedt R 1985 Pharmacological profile of RU486 in animals. In The Antiprogestin Steroid RU486 and Human Fertility Control, pp 49-68. Eds EE Baulieu \& SJ Segal. New York: Plenum Press.

Putnam CD, Brann DB \& Mahesh VB 1991 Acute activation of the adrenocorticotropin-adrenal axis: effects on gonadotropin and prolactin secretion in the female rat. Endocrinology 128 2558-2566.

Rao IM \& Mahesh VB 1986 Role of progesterone in the modulation of the preovulatory surge of gonadotropins and ovulation in the pregnant mare's serum gonadotropin primed immature rat and the adult rat. Biology of Reproduction 35 1154-1161.

Sahu A, Crowley WR, Tatemoto K, Balasubramaniam A \& Kalra SP 1987 Effect of neuropeptide Y, NPY analog (norleucine ${ }^{4}-\mathrm{NPY}$ ), galanin and neuropeptide $\mathrm{K}$ on $\mathrm{LH}$ release in ovariectomized (ovx) and ovx estrogen, progesterone-treated rats. Peptides 8 921-926.

Sánchez-Criado JE, Bellido C, Galiot F, López FJ \& Gaytán F 1990 A possible dual mechanism of the anovulatory action of antiprogesterone RU486 in the rat. Biology of Reproduction $\mathbf{4 2}$ $877-886$. 
Sánchez-Criado JE, Bellido C, López FJ \& Galiot F 1992a Antiprogesterone RU486 induces dissociation of $\mathrm{LH}$ and $\mathrm{FSH}$ secretion in the cyclic rat: effect of anti-inhibin serum. Journal of Endocrinology 134 43-49.

Sánchez-Criado JE, Uilenbroek JThJ \& de Jong FH $1992 b$ Antiprogesterone RU486 increases serum immunoreactive inhibin levels and LH:FSH and testosterone:estradiol ratios in cyclic rats. Journal of Endocrinology 134 51-57.

Sánchez-Criado JE, Galiot F, Bellido C, Gonzalez D \& Tébar M 1993 Hypothalamus-pituitary-ovarian axis in cyclic rats lacking progesterone actions. Biology of Reproduction 48 916-925.

Sánchez-Criado JE, Hernandez G, Bellido C, Gonzalez D, Tébar M, Diaz-Cruz MA \& Alonso R 1994 Periovulatory LHRH, LH and FSH secretion in cyclic rats treated with RU486: effects of exogenous LHRH and LHRH antagonist on LH and FSH secretion at early oestrus. Journal of Endocrinology 141 7-14.

Sánchez-Criado JE, Bellido C, Tébar M, Ruiz A \& Gonzalez D 1999 The antiprogestin RU486 dissociates $\mathrm{LH}$ and FSH secretion in male rats: evidence for direct action at the pituitary level. Journal of Endocrinology 160 197-203.

Sarkar DK \& Fink G 1979 Effects of gonadal steroids on output of luteinizing hormone releasing factor into pituitary stalk blood in the female rat. Journal of Endocrinology 80 303-313.

Sarkar DK, Chiappa SA, Fink G \& Sherwood NM 1976 Gonadotropinreleasing hormone surge in pro-oestrus rats. Nature 264 461-463.

Smith MS, Freeman ME \& Neill JD 1975 The control of progesterone secretion during the estrous cycle and early pregnancy in the rat: prolactin, gonadotropin and steroid levels associated with rescue of the corpus luteum of pseudopregnancy. Endocrinology 96 219-226.

Szabo M, Knox KL, Ringstrom SJ, Perlyn CA, Sutandi S \& Schwartz NB 1996 Mechanism of the inhibitory action of RU486 on the secondary follicle-stimulating hormone surge. Endocrinology 137 $85-89$.

Szabo M, Kilen SM, Saberi S, Ringstrom SJ \& Schwartz NB 1998 Antiprogestins suppress basal and activin-stimulated folliclestimulating hormone secretion in an estrogen-dependent manner. Endocrinology $1392223-2228$.

Tébar M, Bellido C \& Sánchez-Criado JE 1995a Evidence for a permissive effect of extraovarian steroids on the release of FSH at early estrus in rats lacking inhibin secretion or action. Neuroendocrinology Letters 17 21-27.

Tébar M, Bellido C \& Sánchez-Criado JE 1995 b Luteinizing hormone $(\mathrm{LH})$ and corticosterone in proestrous afternoon restore the follicle-stimulating hormone secretion at early estrus in adrenalectomized LH-releasing hormone antagonist-treated rats. Biology of Reproduction 52 63-67.

Tébar M, Ruiz A \& Sánchez-Criado JE 1996 Hypersecretion of follicle-stimulating hormone (FSH) on estrous afternoon in rats treated with RU486 in proestrus. Cellular and Molecular Neurobiology 16 421-426.

Turgeon JL \& Waring DW 1994 Activation of the progesterone receptor by the gonadotropin-releasing hormone self-priming signaling pathway. Molecular Endocrinology 8 860-869.

Waring DW \& Turgeon JL 1992 A Pathway for luteinizing hormone releasing-hormone self-potentiation: cross-talk with the progesterone receptor. Endocrinology 130 3275-3282.

Received 19 February 1999

Revised manuscript received 12 April 1999

Accepted 17 May 1999 